\title{
Efficiency of Certain Evaluated Igrs and Conventional Insecticides on the Incidence of Common Lepidopterous Insect- Pests of Cotton Plant
}

\author{
Awad,H.A., A.Z. El-Naggar, H. M. EL-Bassouiny and Haity M. Tadros. ${ }^{1}$
}

\begin{abstract}
Field studies were conducted in El-Beheira Governorate during the growing cotton season of 2013 to investigate the effect of four IGRs compounds (Ageron ${ }^{\circledR}$, Match $^{\circledR}$, Dimilin ${ }^{\circledR}$ and Topron $\left.^{\circledR}\right)$ against the cotton leaf worm, Spodoptera litorallis (Boisd); six pyrethroids; (Icton $^{\circledR}$, Lamda-Z $^{\circledR}$, Pulsar $^{\circledR}$, Buldock $^{\circledR}$, Sumi-alfa KZ ${ }^{\circledR}$ and Fenerate- $S^{\circledR}$ ) in addition to, Dora ${ }^{\circledR}$ as an organophorous compound against the cotton bollworms; Pectinophora gossypiella (Saund.) and spiny bollworm Earias insulana (Boisd.), besides, the side effects of these tested compounds on cotton yield was also studied.

Results indicated that Topron ${ }^{\circledR}$ gave higher reduction of the cotton leafworm infestation amounted to $85.7 \%$ followed by $\operatorname{Match}^{\circledR}(83.5 \%)$, then, $\operatorname{Ageron}^{\circledR}(82.1 \%)$. For the cotton bollworm, the higher reduction was recorded with Sumi-alfa $\mathrm{KZ}^{\circledR}(\mathbf{8 3 . 6 0 \%})$ followed by Lamda- $Z^{\circledR}$ $(83.2 \%)$, while, Buldock ${ }^{\circledR}$ gave a more lower reduction of $\mathbf{8 0 . 8} \%$. The evaluated percentages of reduction values for the other evaluated insecticides were $82.6 \%$ for Icton $^{\circledR}$, $82 \%$ for Pulsar ${ }^{\circledR}, 82.1 \%$ for Dora ${ }^{\circledR}$ and $81.1 \%$ for Fenerate- $S^{\circledR}$. All the tested insecticides increased the cotton yield in comparison to the untreated check.
\end{abstract}

\section{INTRODUCTION}

Cotton, Gossypium barbadence L. is one of the most important economical crops in Egypt and the world. Due to intensive cultivation of the crops, the list of cotton pests has become very long; implying numerous serious injurious species. Therefore, plant protection has now become a necessity for obtaining good yield. The major insect- pests of cotton plants under study are the cotton leafworm, Spodoptera litorallis (Boisd); the cotton bollworms; pink bollworm, Pectinophora gossypiella (Saund.) \& spiny bollworm Earias insulana (Boisd.) which attack cotton in the subsequent vegetative and fruiting stages of growth. The intensive use of conventional pesticides led to several important drastic problems, i.e. environmental pollution,destruction of the natural enemies and insect resistance to different insecticides Therefore, a great need was attained to develop alternative or/and additional techniques, to allow a rational use of pesticides and provides adequate crop protection for sustainable food, feed and fiber protection. Among the most promising alternatives to the conventional insecticides, are the insect growth regulators (IGRs) that are biorotional insecticides with novel modes of action where they disrupt the development of target pest. Such compounds tend to be selective and generally less toxic to no- target organisms than the conventional insecticides (Biddinger and Hull, 1995 and Nicholas et al., 1999). The use of IGR's compounds in insect control are known as insect development inhibitions, which inhibit or prevent normal metamorphosis of immature stages to the adults stage. Herein, many IGRs have shown potentiality against lepidopterous insects (AbdelAal, 2003 and Seth et al. 2004).

Therefore, the present study aimed to evaluate the efficacy of four insecticides belonged to IGRs; fulufenoxuron $\quad\left(\right.$ Ageron $\left.^{\circledR}\right), \quad$ lufenuron $\left(\right.$ Match $\left.^{\circledR}\right)$, difluubenzuron (Dimilin ${ }^{\circledR}$ ) and chlorfluazuron $\left(\right.$ Topron $^{\mathbb{B}}$ ) against cotton leafworm. The synthetic pyrethroids of lambda-cyhalothrin (Icton $^{\circledR}$, Lamda-Z ${ }^{\circledR}$ and Pulsar ${ }^{\circledR}$ ), beta cyfluthrin (Buldock ${ }^{\circledR}$ ), ES-fenvalerate (Sumi-alfa $\mathrm{KZ}^{\circledR}$ ) and ES-fenvalerate (Fenerate- $\mathrm{S}^{\circledR}$ ); beside, chlorpyrifos $\left(\right.$ Dora $\left.^{\circledR}\right)$ as an organophorous compound were evaluated against the cotton bollworms, in addition to their effect on cotton yield.

\section{MATERIALS AND METHODS}

\section{- Experiment}

Field experiments were carried out at Abo-Homos district, El-Bheira Governorate during season of 2013. Four insect growth regulators (IGRs) were evaluated against the cotton leafworm (CLW) Spodoptera litorallis (Boisd.)as shown in Table (1). The experimental area was consists of five feddans for each treatment which divided into 4 replicates and involved an untreated check. The spraying was carried out on July, the $1^{\text {st }} 2013$.

The performed treatments six pyrethroids and one organophosphorous insecticides were also evaluated against the cotton bollworms (Table 1). For all tested compounds three sprays were done with two weeks interval between sprays. The application of insecticides was started on August, the $15^{\text {th }}, 2013$. In all treatments one back motor was used with 80 liter of spraying preparation / feddan, for each compound.

\footnotetext{
${ }^{1}$ Plant Protection Res., Institute Agric. Res. Centre., Alex., Egypt Email:alyelnaggar31@gmail.com, alyelnaggar@ymail.com Received April 10, 2014, Accepted June 2, 2014
} 
Table 1. The tested pesticides and their application rates which used in this study

\begin{tabular}{|c|c|}
\hline Pesticides & $\begin{array}{c}\text { Rate of application / } \\
\text { feddan }\end{array}$ \\
\hline Fulufenoxuron10\% DC $\left(\right.$ Ageron $\left.^{\circledR}\right)$ & $200 \mathrm{~cm}^{3}$ \\
\hline Lufenuron $5 \%$ EC $\left(\right.$ Match $\left.^{\circledR}\right)$ & $100 \mathrm{~cm}^{3}$ \\
\hline Diflubenzuron 48\% SC $\left(\right.$ Dimilin $\left.^{\mathbb{B}}\right)$ & $125 \mathrm{~cm}^{3}$ \\
\hline Chlorfluazuron $5 \%$ EC (Topron $\left.{ }^{\circledR}\right)$ & $400 \mathrm{~cm}^{3}$ \\
\hline Lambda-Cyhalothrin $2.5 \%$ EC $\left(\right.$ Icton $\left.^{\circledR}\right)$ & Pyrethroids \\
\hline Lambda-Cyhalothrin $5 \%$ EC (Lamda-Z ${ }^{\mathbb{B}}$ ) & Pyrethroids \\
\hline Lambda-Cyhalothrin $5 \%$ EC (Pulsar $\left.{ }^{\mathbb{R}}\right)$ & Pyrethroids \\
\hline Beta Cyfluthrin $12.5 \%$ SC $\left(\right.$ Buldock $\left.^{\circledR}\right)$ & Pyrethroids \\
\hline ES-Fenvalerate $5 \%$ EC (Sumi-alfa $\mathrm{KZ}^{\mathbb{B}}$ ) & Pyrethroids \\
\hline Esfenvalerate $5 \%$ EC (Fenerate- $\left.\mathrm{S}^{\mathbb{B}}\right)$ & Pyrethroids \\
\hline Chlorpyrifos $48 \%$ EC $\left(\right.$ Dora $\left.^{(B)}\right)$ & 1Litre \\
\hline $\begin{array}{l}\text {-Sampling technique: } \\
\text {-The cotton leafworm (CLW) Spodoptera litorallis } \\
\text { (Boisd.) }\end{array}$ & $\begin{array}{l}\text { untreated check (1168 larvae } / 100 \text { plants). The } \\
\text { maximum efficient toxic effect was recorded at the } 7^{\text {th }} \\
\text { day post application for Topron }{ }^{\circledR}(114.75 \text { larvae } / 100 \\
\text { plants), followed by } \operatorname{Match}^{\circledR} \text { and Dimilin }{ }^{\circledR}(142.75\end{array}$ \\
\hline $\begin{array}{l}\text { Randomly; } 100 \text { cotton plants were chosen from each } \\
\text { replicate ( } 400 \text { plants per each treatment) to count the } \\
\text { CLW larvae in the early morning before and after } \\
\text { treatment. Examination was performed after three days } \\
\text { with non-conventional compounds (IGR's) in order to } \\
\text { calculate the initial reduction effect (I.R.E.) The } \\
\text { examination was furtherly after } 7 \text { and10 days to } \\
\text { calculate the latent reduction effect (L.R.E.). The rate of } \\
\text { infestation reduction was calculated for comparison, } \\
\text { according to Henderson and Tilton (1955). }\end{array}$ & $\begin{array}{l}\& 147.25 \text { larvae } / 100 \text { plants, in respect). The same trend } \\
\text { of toxic activity was detected at the } 10^{\text {th }} \text { days from } \\
\text { spraying (Table, 2). The overall mean of the larval } \\
\text { account was significantly differed between treatments, } \\
\text { indicating that the lowest mean number of the inspected } \\
\text { larvae was determined for Topron }{ }^{\circledR}(122.08 \text { larvae } / 100 \\
\text { plants), versus, the highest recorded mean numbers } \\
\left(195.25 / 100 \text { plants) for Ageron }{ }^{\circledR} \text { treatment; in }\right. \\
\text { comparison to the untreated check }(998.75 \text { larvae } / 100 \\
\text { plants). }\end{array}$ \\
\hline
\end{tabular}

\section{- The cotton bollworms:}

Weekly samples of 100 green bolls were collected from each replicate (400 bolls per each treatment) just before spraying and after 7 and 14 days of each spray; they were externally and internally examined. The numbers of inspected larvae in green bolls were calculated. The percentage of reduction was calculated according to the equation of Henderson and Tilton (1955).

\section{- Determination of cotton yield}

In each treatment ripened open bolls from twenty five cotton plants were collected to estimate the cotton yield / plant, from which, the total yield / feddan was relatively calculated.

\section{RESULTS AND DISCUSSION}

\section{-Effect of IGRs compounds on cotton leafworm}

The results in Table (2) show, the insignificant difference in detected efficiency between treatments after 3 days of application where the mean numbers of counted larvae amounted to 254.75, 195, 209.25 and 163.75 larvae $/ 100$ plants for Ageron ${ }^{\circledR}$, Match $^{\circledR}$, Dimilin $^{\circledR}$ and Topron ${ }^{\circledR}$, respectively but still less than
This results were ascertained by the included results in Table,3. Herein, the higher value of Initial reduction effect was recorded after application with Topron $^{\circledR}$ (83.4\%), followed by Match ${ }^{\circledR}$ treatment $(81.1 \%)$, while, Ageron ${ }^{B}$ gave the least effect $(79.8 \%)$. Also, the latent reduction effect values were $86.9 \%, 84.2 \%, 84.7 \%$ and $83.2 \%$ with $\operatorname{Topron}^{\circledR}$, Dimilin ${ }^{\circledR}$, Match $^{\circledR}$ and Ageron ${ }^{\circledR}$ treatments, respectively. In general, it could be confirmed that the treatment of Topron ${ }^{\circledR}$ gave the highest overall mean of reduction $(85.7 \%)$, while the treatment of Ageron $^{\circledR}$ gave the least reduction $82.1 \%$ (Table, 3).

The above cited results are in agreement with findings of Clarke and Jewess (1990) who showed that the enhanced toxicity of Flufenoxuron to S. littoralis compared with Diflubenzuron can probably be attributed to its slow metabolism and reduced excretion. Rao and Subbaratnam (2000) proved that Flufenoxuron was relatively more toxic than either Diflubenzuron or Lufenuron on the third instars larvae of S. exigua. YuXian et al. (2003) 

Table 3. The calculated percentage of reduction of cotton Leafworm after application of IGRs

\begin{tabular}{|c|c|c|c|c|c|}
\hline \multirow{3}{*}{ Inspection dates } & \multirow{3}{*}{ Replicates } & \multicolumn{4}{|c|}{ The percentage Reduction \% } \\
\hline & & \multicolumn{4}{|c|}{ Treatments } \\
\hline & & Ageron $^{\circledR}$ & Match $^{\circledR}$ & Dimilin $^{\circledR}$ & Tobron ${ }^{\circledR}$ \\
\hline \multirow{4}{*}{3 Days } & 1 & 82.5 & 83.5 & 80.9 & 84.1 \\
\hline & 2 & 79.8 & 81.3 & 80.2 & 84.9 \\
\hline & 3 & 78.7 & 80.7 & 79.8 & 83.5 \\
\hline & 4 & 78.1 & 78.9 & 78.2 & 80.9 \\
\hline M. Reduction $\%$ & & 79.8 & 81.1 & 79.8 & 83.4 \\
\hline I.R.E* & & 79.8 & 81.1 & 79.8 & 83.4 \\
\hline \multirow{4}{*}{7 Days } & 1 & 84.8 & 85.8 & 84.1 & 86.6 \\
\hline & 2 & 84.4 & 84.9 & 83.4 & 87.8 \\
\hline & 3 & 80.6 & 82.4 & 83.5 & 86.3 \\
\hline & 4 & 84.3 & 84.1 & 84.8 & 86.6 \\
\hline M. Reduction $\%$ & & 83.6 & 84.3 & 84.0 & 86.8 \\
\hline \multirow{4}{*}{10 Days } & 1 & 83.6 & 84.7 & 84.5 & 86.1 \\
\hline & 2 & 84.9 & 85.7 & 84.1 & 87.9 \\
\hline & 3 & 80.5 & 83.4 & 84.09 & 87.2 \\
\hline & 4 & 82.4 & 86.3 & 84.8 & 86.9 \\
\hline M. Reduction $\%$ & & 82.9 & 85.1 & 84.3 & 87.03 \\
\hline L.R.E** & & 83.2 & 84.7 & 84.2 & 86.9 \\
\hline \multicolumn{2}{|c|}{ Overall Mean of Reduction } & 82.1 & 83.5 & 82.7 & 85.7 \\
\hline
\end{tabular}

*I.R.E = Initial Reduction \% Effect ** L.R.E =Latent Reduction \% Effect

mentioned that the deduced inhibition values for carboxylesterase activity after feeding the second-instar larvae of $S$. exigua on treated leaves with Chlorfluazuron (50 mg/litre) was $60.56 \%$. EL-Naggar et. al. (2012) found that the general mean of larval reduction was $87.5 \%$ for Cabris ${ }^{\circledR}$, while it was $85.3 \%$ for Cascade ${ }^{\circledR}$. Also, Ghoneim et. al. (2012) reported that the IGRs (lufenuron, Flufenoxuro, Tobufenozite, Hexaflumuron, Triflumuron and Chlorfluazuron) exhibited low levels of resistance on both the stages of eggs and larvae, andthey had higher toxic action on larvae than that on eggs.

\section{-Efficacy of the evaluated insecticide on the cotton bollworm}

The implied results in $($ Table,4) elucidate that after the first spray, Lamda- $Z^{\circledR}$ gave the least mean number of infested bolls (1.1/100bolls), while, for the other treatments ranged from 1.2 for Icton ${ }^{\circledR}$ to $2.1 / 100$ bolls for Sumi-alfa $\mathrm{KZ}^{\circledR}$ compared to the untreated check (10.9 /100 bolls). However, after the second and third sprays, there were no significant differences between the tested compounds where they gave means values of infested bolls ranged between 1.2 and $1.6 / 100$ bolls after the second spray and from 1.5 to $2.6 / 100$ bolls after the third spray in comparison with the untreated check (12.6 and 16 infested bolls /100 bolls, respectively). The calculated overall means of infested bolls $/ 100$ bolls amounted to $1.29,1.58,1.66,1.70$, 1.75, 1.79 and 2.0 for Lamda- $Z^{\circledR}$, Dora ${ }^{\circledR}$, Sumi-alfa $\mathrm{KZ}^{\circledR}$, Icton $^{\circledR}$, Pulsar ${ }^{\circledR}$, Fenerate- $\mathrm{S}^{\circledR}$ and Buldock ${ }^{\circledR}$, respectively (Table,4).

Moreover, the exhibited data in Table, 5, show that the performed treatments of Icton ${ }^{\circledR}$, Lamda-Z ${ }^{\circledR}$, Dora ${ }^{\circledR}$, Buldock $^{\circledR}$ and Fenerate- $S^{\circledR}$ gave high reduction of infested bolls after the first spray comprised 89, 86.1, $86.4,84.2$ and $86 \%$, but thes values consequently, more or less decreased after the $2^{\text {nd }}$ spray up to $76.6,80.3$, $77.5,76.6$ and $78.4 \%$, respectively; and after the $3^{\text {rd }}$ spray up to $82.3,83.2,82.5,81.5$ and $81.1 \%$, in respect. Moreover, the treatment of Sumi-alfa $K Z^{\circledR}$ gave the more lower of $80.8 \%$ reduction after the first spray, then increased to $87.5 \%$ after the second one, but decreased again $82.4 \%$ after the third spray. In general, the overall means reduction values were higher for the treatments of Sumi-alfa KZ ${ }^{\circledR}$ and Lamda- $Z^{\circledR}$ (83.60 and 83.2), while they were $82.6,82.1,82,81.1$ and 80.8 for Icton $^{\circledR}$, Dora $^{\circledR}$, Pulsar ${ }^{\circledR}$, Fenerate- $S^{\circledR}$ and Buldock ${ }^{\circledR}$, respectively.

The above mentioned results are in agreement with the concluded results by Mahar et al. (2004), who reported that, Fenpropathrin, Chlorpyrifos and Endosulfan insecticides were effective against the pink bollworm. 
Sandeep et al. (2006) who stated that the lowest averages of infestation rates at the $14^{\text {th }}$ day after spraying were obtained with Cypermethrin + Chlorpyrifos (5.05\%), Beta- Cyfluthrin $2.5 \%$ EC (4.64 $\%)$, Spinosad $45 \%$ SC (4.19\%) and Indoxacarb $14.5 \%$ EC (4.71\%). EL-Mageed et al. (2007) mentioned that the programme of (Beta-Cyfluthrin, Malathion and Spinosad for the $1^{\text {st }}, 2^{\text {nd }}$ and $3^{\text {rd }}$ spray, respectively) resulted in the greatest reduction $(81.04$ and $81.08 \%)$ in pink bollworm larval population. The percentage of infestation by the spiny bollworm was very low. Abd EL-Rahman et al. (2009) indicated that the highest biological performance against the pink bollworm $(P$. gossypiella) was achieved by using of $\alpha$-cyhalothrin at $100 \mathrm{ml} /$ fed. (92.7\%).

\section{-Effect of certain insecticides on cotton yield}

The higher percentage of cotton yield increase than the untreated check was recorded after application with the insecticide- Sumi-alfa $\mathrm{KZ}^{\circledR}$, which gave $63.3 \%$ increase followed by Lamda- $Z^{\circledR}(61.7 \%)$, versus, the lower increase of cotton yield $(41.7 \%)$ after Buldock ${ }^{\circledR}$ application. For the other treatments, the calculated percentage values of cotton yield increase ranged from $51.7 \%$ for Pulsar ${ }^{\circledR}$ to $56.7 \%$ for the organophosporous one-Dora $^{\circledR}(56.7 \%)($ Table, 6$)$.

Table 5. The calculated percentage of reduction of infested bolls with bollworms after application of evaluated insecticides

\begin{tabular}{|c|c|c|c|c|c|c|c|c|c|}
\hline \multirow{3}{*}{$\begin{array}{l}\text { N. } \\
\text { Spray }\end{array}$} & \multirow{3}{*}{ Inspections } & \multirow{3}{*}{ Replicates } & \multicolumn{7}{|c|}{ The percentage Reduction \% } \\
\hline & & & \multicolumn{7}{|c|}{ Insecticides } \\
\hline & & & Icton $^{\circledR}$ & Lamda-Z $^{\circledR}$ & Bulsar $^{\circledR}$ & Bulldock $^{\circledR}$ & $\begin{array}{c}\text { 'Sumi- } \\
\text { alfa'KZ }\end{array}$ & Dora $^{\circledR}$ & $\begin{array}{l}\text { Fenerate- } \\
\text { S }\end{array}$ \\
\hline \multirow{10}{*}{$\begin{array}{c}1^{\text {st }} \\
\text { Spray }\end{array}$} & \multirow{5}{*}{$\begin{array}{c}1^{\text {st }} \\
\text { inspection }\end{array}$} & 1 & 88 & 94 & 82 & 73 & 82 & 82 & 88 \\
\hline & & 2 & 89 & 83.5 & 89 & 78 & 78 & 83.5 & 83.5 \\
\hline & & 3 & 92 & 84 & 84 & 84 & 84 & 89.3 & 89.3 \\
\hline & & 4 & 88.5 & 88.5 & 88.5 & 84.7 & 77 & 88.5 & 88.5 \\
\hline & & M. R.\% & 89.4 & 87.5 & 85.9 & 79.9 & 80.3 & 85.8 & 87.3 \\
\hline & \multirow{5}{*}{$\begin{array}{c}2^{\text {nd }} \\
\text { inspection }\end{array}$} & 1 & 89.3 & 89.3 & 76 & 84 & 84 & 84 & 89.3 \\
\hline & & 2 & 91 & 86.5 & 82 & 91 & 82 & 86.5 & 86.5 \\
\hline & & 3 & 89 & 78 & 78 & 89 & 89 & 92.7 & 92.7 \\
\hline & & 4 & 85 & 85 & 85 & 90 & 70 & 85 & 70 \\
\hline & & M. R.\% & 88.6 & 84.7 & 80.3 & 88.5 & 81.3 & 87.05 & 84.6 \\
\hline \multicolumn{3}{|c|}{$\begin{array}{l}\text { General Means Reduction \% of } \\
\text { Spray }\end{array}$} & 89 & 86.1 & 83.1 & 84.2 & 80.8 & 86.4 & 86 \\
\hline \multirow{10}{*}{$\begin{array}{c}2^{\text {nd }} \\
\text { Spray }\end{array}$} & \multirow{5}{*}{$\begin{array}{c}3^{\text {rd }} \\
\text { inspection }\end{array}$} & 1 & 77.5 & 85 & 90 & 85 & 90 & 77.5 & 85 \\
\hline & & 2 & 75 & 75 & 87.5 & 75 & 87.5 & 75 & 75 \\
\hline & & 3 & 82 & 82 & 82 & 82 & 82 & 82 & 82 \\
\hline & & 4 & 77 & 77 & 77 & 77 & 88.5 & 77 & 77 \\
\hline & & M. R.\% & 77.9 & 79.8 & 84.1 & 79.8 & 87 & 77.9 & 79.8 \\
\hline & \multirow{5}{*}{$\begin{array}{c}4^{\text {th }} \\
\text { inspection }\end{array}$} & 1 & 79 & 86 & 90.7 & 72 & 90.7 & 86 & 86 \\
\hline & & 2 & 77 & 77 & 77 & 77 & 88.5 & 77 & 77 \\
\hline & & 3 & 70 & 85 & 70 & 70 & 85 & 70 & 70 \\
\hline & & 4 & 75 & 75 & 75 & 75 & 87.5 & 75 & 75 \\
\hline & & M. R.\% & 75.3 & 80.8 & 78.2 & 73.5 & 87.9 & 77 & 77 \\
\hline \multicolumn{3}{|c|}{ General Means Numbers of Spray } & 76.6 & 80.3 & 81.2 & 76.7 & 87.5 & 77.5 & 78.4 \\
\hline \multirow{10}{*}{$\begin{array}{c}3^{\text {rd }} \\
\text { Spray }\end{array}$} & \multirow{5}{*}{$\begin{array}{c}5^{\text {th }} \\
\text { Inspection }\end{array}$} & 1 & 82.7 & 80.5 & 80.5 & 87 & 74 & 80.5 & 87 \\
\hline & & 2 & 79 & 79 & 79 & 79 & 79 & 79 & 79 \\
\hline & & 3 & 83.5 & 89 & 83.5 & 78 & 89 & 83.5 & 83.5 \\
\hline & & 4 & 81 & 81 & 81 & 81 & 81 & 81 & 71.5 \\
\hline & & M. R.\% & 81.6 & 82.4 & 81 & 81.3 & 80.8 & 81 & 80.3 \\
\hline & \multirow{5}{*}{$\begin{array}{c}6^{\text {th }} \\
\text { Inspection }\end{array}$} & 1 & 82.7 & 80.5 & 80.5 & 83.8 & 80.5 & 80.5 & 87 \\
\hline & & 2 & 84 & 84 & 84 & 84 & 84 & 84 & 84 \\
\hline & & 3 & 82 & 88 & 82 & 76 & 88 & 88 & 82 \\
\hline & & 4 & 83 & 83 & 83 & 83 & 83 & 83 & 74.5 \\
\hline & & M. R.\% & 82.9 & 83.9 & 82.4 & 81.7 & 83.9 & 83.9 & 81.9 \\
\hline \multicolumn{3}{|c|}{ General Means Reduction of Spray } & 82.3 & 83.2 & 81.7 & 81.5 & 82.4 & 82.5 & 81.1 \\
\hline \multicolumn{3}{|c|}{ Overall Mean of Reduction } & 82.6 & 83.2 & 82 & 80.8 & 83.60 & 82.1 & 81.1 \\
\hline
\end{tabular}


Table 6. Effect of tested insecticides on cotton yield

\begin{tabular}{|c|c|c|}
\hline \multirow[b]{2}{*}{ Insecticides } & \multicolumn{2}{|c|}{ Cotton Yield } \\
\hline & $\begin{array}{l}\text { Weight /fdd. } \\
\text { Kg (Kent.) }\end{array}$ & $\begin{array}{c}\%{ }^{*} \\
\text { Increase }\end{array}$ \\
\hline Icton $^{\circledR}$ & $\begin{array}{l}1464.8 \mathrm{Kg} \\
\text { (9.3 Kent.) }\end{array}$ & $55 \%$ \\
\hline Lamda-Z $^{\circledR}$ & $\begin{array}{l}1527.8 \mathrm{Kg} \\
\text { (9.7 Kent.) }\end{array}$ & $61.7 \%$ \\
\hline Pulsar $^{\mathbb{R}}$ & $\begin{array}{l}1433.3 \mathrm{Kg} \\
\text { (9.1 Kent.) }\end{array}$ & $51.7 \%$ \\
\hline Buldock $^{\circledR}$ & $\begin{array}{l}1338.8 \mathrm{Kg} \\
(8.5 \mathrm{Kent} .)\end{array}$ & $41.7 \%$ \\
\hline Sumi-alfa $\mathrm{KZ}^{\circledR}$ & $\begin{array}{l}1543.5 \mathrm{Kg} \\
\text { (9.8 Kent.) }\end{array}$ & $63.3 \%$ \\
\hline Dora $^{\circledR}$ & $\begin{array}{l}1480.5 \mathrm{Kg} \\
(9.4 \text { Kent.) }\end{array}$ & $56.7 \%$ \\
\hline Fenerate-S $S^{\circledR}$ & $\begin{array}{l}1464.8 \mathrm{Kg} \\
\text { (9.3 Kent.) }\end{array}$ & $55 \%$ \\
\hline Untreated Check & $\begin{array}{l}945 \mathrm{Kg} \\
\text { (6 Kent.) }\end{array}$ & - \\
\hline
\end{tabular}

* expressed as \% of increase than the untreated check, according to Hussein et al. (2002).

Identical results were mentioned in the works of Ali et al. (1988) who reported that Carbaryl, Permethrin, Chlorpyrifos insecticides and Moncrotophos increased seed cotton yield. Karner et al. (2003) who mentioned that cotton yields in insecticides- treated plots was $9 \%$ more compared to untreated plots.

Younis et al. (2009) showed that the synthetic pyrethroids induced the greatest reduction in bollworms infestation that was associated with the highest amount of seed cotton yield.

\section{REFERENCES}

Abdel-Aal, A.E. (2003). Effect of some insect growth regulators on certain biological, biochemical and histopathological aspects of the cotton leafworm, Spodoptera littoralis (Boisd.) (Unpublished). Ph.D. Thesis, Fac. of Sci., Cairo Univ., Egypt, 119 p).

Abd El-Rahman, Kh.A, A.Z. EL-Naggar and M. M. ELBassouiny (2009). Biological performance of certain green chemistry pesticides and mixtures against the pink bollworm, Pectinophora gossypiella (Lepidoptera: Gelechiidae) (Saund.) and spiny bollworm, Earias insulana (Lepidoptera: Noctuidae) (Boisd.). Nile Delta Conf. on Exports Crops, Fac. of Agric., Minufiya Univ., $1^{\text {st }}: 335-345$

Ali, M., A. Zahoor., M.R Attique and W. Tajamal (1988). Effect of some insecticides on the growth, fruit development and yield of two cotton varieties in Punjab, Pakistan. Pakistan Cottons, 32 (1): 30-36.

Biddinger, D. J. and L. A. Hull (1995). Effect of several types of insecticides on the mite predator Stethorus punctum (Coleoptera: Coccinellidae),including insect growth regulators and abamectin. J. Econ. Entomol., 88: 358-366.
Clarke, B. S. and P. J. Jewess (1990). The uptake, excretion and metabolism of the acylurea insecticide, flufenoxuron in Spodoptera littoralis larvae, by feeding and topical application. Pesticide Science, Vol. 28, No. 4, pp. 357-365, 17 ref.

EL-Mageed, A.E.A., E.M. Anwar, L.R.A. Elgohary and H.F. Dahi (2007). Evaluation of several programs of sequences pesticides application on cotton bollworms and some other sucking pests in cotton field. J. Ent. 4 (2): 93 - 103.

El-Naggar, A.Z., M.K. Shekeban, Mahasen M. Ibrahim and Mervat H.A. Metayi (2012). Evaluation of certain pesticides on cotton bollwormsand cotton leafworm and their side effect on some prevalent sucking pests. J. Adv. Agric. Res. 17(1):1-19.

Ghoneim, Y.F., M. Singab, Hala M. Abou-Yousef and N. S. Abd-El-Hai (2012). Efficacy of certain insecticides and their mixtures with the tested IGRs against a field strain of the cotton leaf worm, Spodoptera littoralis (Boisd.) under laboratory conditions. Australian Journal of Basic and Applied Sciences, 6(6): 300-304.

Henderson; D. F. and E. W. Tilton (1955). Tests with acaricides against the brown wheat mite. J. Econ. Entomol., 48: 157-161.

Hussin, N.M., F.F. Shalaby, E.F. EL-Khayat, S. M. Tawifik and M.S. Salem (2002). Effect of certain agrochemical on cotton growth and bollworms infestation during three successive seasons at Kalubia Govenorate Egypt. $2^{\text {nd }}$ International Conferences, Plant Protection Research Institute, Cairo, Egypt, 21-24 December,2002, 854-865.

Karner, M. A., R. Price and D. A. Wolfenberger (2003). Factors affecting economic beneficial derived from using insecticides to control bollworm, Helicoverpa zea (Boddie)/tobacco budworm, Heliothis virescens (F.), in 
Oklahoma 1976-1990. Beltwide cotton conferences, Nashville, TN, USA: 1627-1633.

Mahar, A.N., M. Munir, D.A. Darban, A.Q. Mahar and G.S. Markhand (2004). Field evaluation of different insecticides against pink bollworm on four cotton varieties in Sindh, Pakistan. Indus Cottons, 1 (2): $65-72$.

Nicholas, A. H., W. G. Thwaite and R. N.Spooner-Hart. (1999). Arthropod abundance in an disruption and supplementary insecticide treatments for codling moth, Cydia pomonella (L) (Lepidopter: Torticidae) Austral. J.Entomol., 38: 23-29.

Rao, D. V. S. and Subbaratnam, G. V. (2000). Toxicity of benzoylphenylureas to the ragi cutworm, Spodoptera exigua (Hubner) on onion. Pest Management and Economic Zoology, Vol. 8, No. 2, pp. 171-175, 8 ref.

Sandeep, D. Gaikwad and V.K. Bhamare (2006). Efficacy of newer insect growth regulators and insecticides against cotton leafworm. J. Plant Sci., 1(1): 104 - 106.
Seth, R. K., J. J. Kaur, D. K. Rad and S. E.Reynolds (2004). Effect of larval exposure to sublethal concentrations of the ecdysteroid agonists RH-5849 and Tebufenozide (RH5992) on male reproductive physiology in Spodoptera litura. (J.Insect Physiol.; 50 (6): 505- 517).

Younis, A.M.; S.H. Hamouda; S.A. Ibrahim and Z.A.M. Zeitoun (2009). Field evaluation of certain pesticides against the cotton bollworms with special reference to their negative impact on beneficial arthropods (2006 cotton season, Minia region, Egypt). African Crop Science Society Conference, EL-Minia, Egypt, $8^{\text {th }}$ October 27(31): $993-1002$.

YuXian He, Wang ChangFang, Chen Feng, Yang XiuJuan and Weng QiYong (2003): Effects of insecticides on esterase activity in beet armyworm (Spodoptera exigua). Acta Agriculturae Universitatis Jiangxiensis, Vol. 25, No. 6, pp. 896-899, 15 ref.

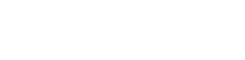

\section{قفيم كهاءة بصض مركبلت مقلملت النمو الهشربة والمركبلت القليية عل خفض هستوبلت الإلبة بأُكلت النمان الهشربة من رتبة حرشفية الأجنحة}

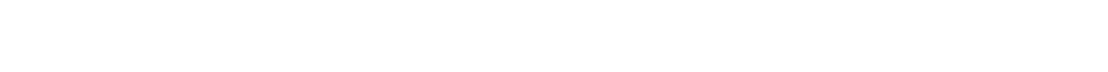

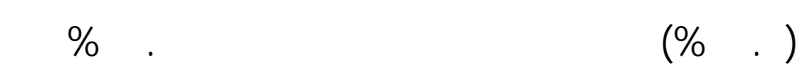

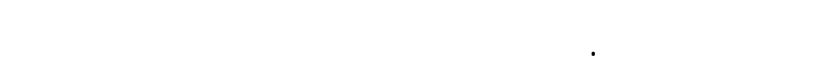

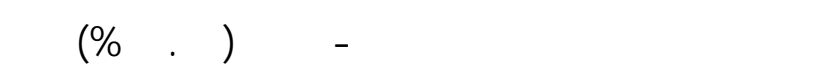

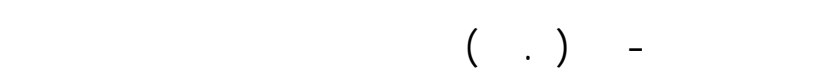

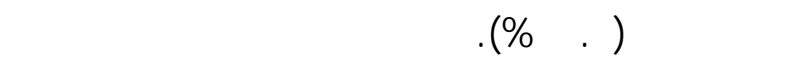

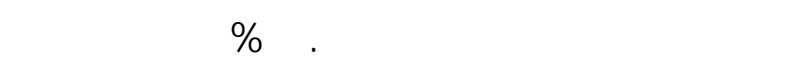

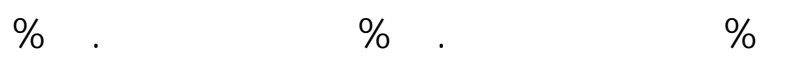

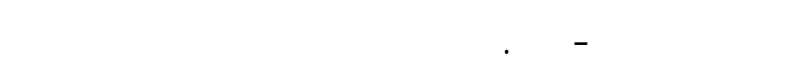
مبلثر فى زياة محصول التطن مقارنة بالكنترول.

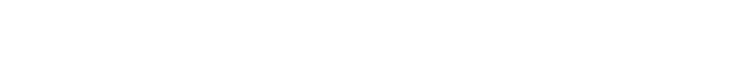

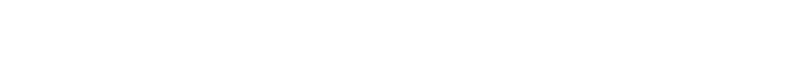



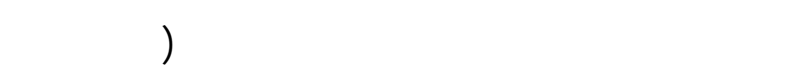

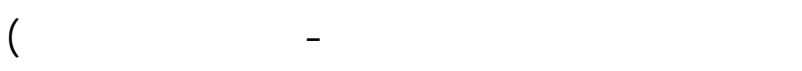
بالإضفة إلى مركب دورا كمركب فوسفورى ضد الإند ديدان

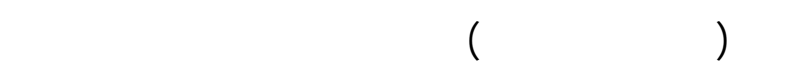
إنتلجية محصول التطن.

أوضنحت النتائج أن مركب توبرون أعلى معل خفض

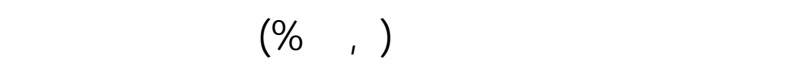

